\title{
IDENTIFIKASI LOKASI POTENSIAL UNTUK PEMENUHAN RUANG TERBUKA HIJAU (RTH) PUBLIK AKTIF DI KOTA SALATIGA
}

\author{
Identifying Potential Locations to Fulfill the Need for Active Public \\ Green Open Space in Salatiga City
}

\section{Martha Rosdiana Utami ${ }^{1}$ dan Retno Susanti ${ }^{1}$}

Diterima: 11 September 2018

Disetujui: 17 Oktober 2018

\begin{abstract}
Abstrakt: Kondisi Ruang Terbuka Hijau (RTH) Kota Salatiga belum mencapai 30\%, saat ini RTH Publik sebesar 5,61\% dan RTH Privat 6,4\%. RTH publik aktif baru tersebar di tiga kecamatan, sesuai Peraturan Menteri Pekerjaan Umum Nomor 05/PRT/M/2008 tentang pedoman penyediaan dan pemanfaatan RTH di kawasan perkotaan, RTH publik aktif harus disediakan minimal satu taman untuk setiap adminimistrasi dari skala terkecil RT, RW, Kelurahan, Kecamatan dan Kota. Tujuan dari penelitian ini adalah untuk mengidentifikasi lokasi potensial untuk pemenuhan RTH publik aktif di Kota Salatiga. Kesesuaian lokasi RTH menggunakanan analisis Weighted Overlay dengan mengambil nilai Percent of Influence atau bobot menggunakan metode Analytic Hierachy Proccess (AHP) terhadap 4 narasumber ahli. Hasil analisis ini berupa peta kesesuaian lokasi RTH publik aktif memiliki masing-masing luas yaitu kelas sesuai sebesar $26,12 \%$,kelas cukup sesuai sebesar 59,27\% dan kelas tidak sesuai sebesar $12,54 \%$ dari luas wilayah kota Salatiga. Penelitian ini merupakan penelitian baru, karena hasil akhir dari penentuan lokasi RTH Publik Aktif berupa 29 titik kavling lokasi lahan milik pemerintah menggunakan analisis intersect pada SIG. Penelitian ini sebagai tindak lanjut bagi pemerintah Kota Salatiga untuk membuat kebijakan disinsentif terkait pemenuhan $\mathrm{KDH}$, misalnya pengenaan pajak dan kompensasi yang dapat digunakan untuk penggantian lahan hijau yang dapat disediakan pemerintah.
\end{abstract}

\section{Keyword:Identifikasi, lokasi potensial, RTH publik aktif}

\begin{abstract}
The condition of Green Open Space (or Open Space) in Salatiga City has not reached the minimum standard of $30 \%$, as the public Open Space in this City was still $5.61 \%$, and Private Open Space was 6.4\%. Active Public Open Spaces were distributed in three sub districts. Minister of Public Work's Regulation Number05/PRT/M/2008 about guidelines of Open Space providing and utilization in urban area mentions that active public open space should provide at least a park for each of administration at smallest scale of RT (neighborhood association), RW (citizens associations), Kelurahan, Sub District and City. For that reason, identification should be made on the potential location to be developed into active public open space. The compatibility of Open Space location was analyzed using Weighted Overlay analysis taking Percent of Influence value or weight with Analytic Hierachy Proccess (AHP) method to 4 exspert . The result of analysis was the map of compatibility of active public Open Space location with respective width of 26,12\% for compatible class, 59,27\% for adequate class, and 12,54\% for incompatible class. This research
\end{abstract}

\footnotetext{
${ }^{1}$ Departemen Perencanaan Wilayah dan Kota, Fakultas Teknik, Universitas Diponegoro
} 
is a new research, because the final result of determining the location of Active Public RTH in the form of 29 points of location of government-owned land using intersect analysis on GIS. This study is a follow-up for the Salatiga City government to create a disincentive policy related to the fulfillment of $\mathrm{KDH}$, such as the imposition of taxes and compensation that can be used to replace green land that the government can provide.

Keywords: identification, potential location, active public Open Space

\section{PENDAHULUAN}

Kota Salatiga merupakan salah satu kota di Jawa Tengah memiliki luas wilayah sebesar 5.678,11 Ha mengalami laju pertumbuhan penduduk sebesar 1,16\% per tahun (BPS Kota Salatiga, 2016). Adanya pertumbuhan penduduk ini dapat diindikasikan akan mempengaruhi peningkatan lahan terbangun dan berakibat pada minimnya RTH. Terbukti menurut data RTRW Kota Salatiga Tahun 2010-2030, RTH Publik di Kota Salatiga baru sebesar $260 \mathrm{Ha}$ atau 4,6\% dari luas wilayah, dan RTH Privat sebesar $365 \mathrm{Ha}$ atau 6,4\% dari luas wilayah. Kondisi RTH tersebut menyebabkan beberapa warga mengeluhkan bahwa Kota Salatiga tidak sesejuk dahulu, suhu Kota Salatiga dianggap terus meningkat seiring peningkatan aktivitas manusia terkait pembangunan fisik dan transportasi yang tidak dibarengi dengan peningkatan vegetasi. Beberapa penyebab belum terpenuhinya nilai minimal RTH yaitu minimnya RTH Privat disebabkan karena minimnya Koefisien Dasar Hijau $(\mathrm{KDH})$ yang disediakan setiap kavling. Tim monitoring Dinas Pekerjaan Umum dan Penataan Ruang Kota Salatiga banyak menemukan kavling perumahan yang memiliki luas tipe kecil dan rumah tumbuh tidak memiliki nilai $\mathrm{KDH}$. Ketentuan nilai $\mathrm{KDH}$ setiap kavling sudah diatur dalam dokumen Pertimbangan Teknis Tata Ruang (PTTR) yang dikeluarkan oleh Dinas Pekerjaan Umum dan Penataan Ruang Kota Salatiga. Ketentuan KDH memiliki arti bahwa masyarakat wajib untuk turut ikut serta secara aktif dalam penyediaan ruang terbuka hijau setiap kavling dengan menyisakan lahan yang dialokasikan untuk daerah hijau (Ismaun, 2011). Seharusnya KDH setiap kavling sebagai penyumbang RTH privat yang harus disediakan minimal $10 \%$ dari total luas wilayah.

Permasalahan KDH sebagai penyumbang RTH Privat, memicu suatu desakan untuk memaksimalkan RTH Publik sebagai tanggung jawab pemerintah. Berbagai upaya telah dilakukan pemerintah untuk mengembangkan RTH Publik yaitu salah satunya dengan Program Pengembangan Kota Hijau (P2KH). Bentuk dari program P2KH yaitu Taman Tingkir dan Taman Bendosari. Dengan adanya program tersebut Kota Salatiga memiliki Ruang Terbuka Hijau Publik Aktif yang selama ini hanya ada satu yaitu lapangan alun-alun Pancasila. Lokasi alun-alun Pancasila berada di Kecamatan Sidomukti, Taman Tingkir berada di Kecamatan Tingkir dan Lokasi Taman Bendosari di Jalan Lingkar Salatiga mengindikasikan lokasi RTH Publik Aktif tersebut belum mampu menjawab kebutuhan RTH Publik Aktif yang mempertimbangkan segi sasaran pengunjung, jarak, aksesibilitas dan sebarannya. Hal tersebut dikeluhkan warga yang berada diluar kecamatan lokasi taman, karena warga merasa jauh dan kesulitan untuk mencapai taman tersebut. Sehingga dapat dikatan RTH Publik aktif berupa taman di Kota Salatiga saat ini belum mencukupi kebutuhannya. Dalam Peraturan Menteri Pekerjaan Umum Nomer 5 Tahun 2008 tentang Pedoman Penyediaan RTH diperkotaan, suatu taman wajib disediakan minimal satu taman untuk setiap adminimistrasi dari skala terkecil RT, RW, Kelurahan, Kecamatan dan Kota dengan memperhatikan sebarannya dan minimal luasan taman untuk setiap skala lingkungan. Untuk itu perlu dilakukan identifikasi terkait lokasi yang potensial untuk dikembangkan menjadi RTH Publik Aktif, karena penentuan lokasi RTH akan berpengaruh pada optimalnya RTH Publik Aktif pada wilayah perkotaan, sehingga pembangunan kota yang berwawasan lingkungan dan pemenuhan kelangsungan hidup hayati setiap manusia dapat terwujud. Dengan adanya penelitian ini diharapkan dapat menjadi bahan 
pertimbangan bagi pihak pemerintah dan pemangku kepentingan dalam mewujudkan RTH Publik Aktif yang optimal.

\section{Definisi Ruang Terbuka Hijau}

Ruang terbuka hijau merupakan kawasan atau area yang memiliki bentuk memanjang dan mengelompok dengan tidak terdapat bangunan dan memiliki sifat terbuka yang ditumbuhi tanaman baik secara alami maupun disengaja (Permen PU No.5, 2008). Ruang terbuka hijau merupakan bagian dari ruang publik sebagai tempat interaksi sosial masyarakat di kawasan perkotaan dan sekitarnya (Carr, 1992)

\section{Jenis Ruang Terbuka Hijau}

Berdasarkan kepemilikannya, RTH Publik dan RTH Privat. RTH Publik Merupakan ruang yang digunakan untuk kepentingan masyarakat atau publik yang dimiliki dan dikelola oleh pemerintah daerah kota atau kabupaten, dengan proporsi minimal $20 \%$ dari luas total wilayah perkotaan. Sedangkan RTH Privat merupakan ruang untuk kalangan terbatas seperti halaman rumah dan gedung, kebun yang ditanami tumbuhan yang dimiliki dan diolah oleh institusi tertentu masyarakat dan atau swasta. Dengan proporsi minimal $10 \%$ dari luas total wilayah perkotaan. Berdasarkan jenis kegiatan, Ruang Terbuka Aktif dan Ruang Terbuka Pasif (Rustama Hakim, 1987) Ruang Terbuka Aktif, merupakan ruang terbuka yang memiliki bentuk tempat bermain, taman, plaza, tempat rekreasi yang digunakan sebagai tempat aktivitas dan kegiatan seperti jalan-jalan, olahraga dan bermain. Ruang Terbuka Pasif, merupakan ruang terbuka yang memeiliki bentuk seperti penghijauan tepi jalur jalan, penghijauan tepian bantaran sungai, penghijauan ditepian rel kereta api dan penghijauan daerah yang bersifat alamiah dengan fungsi sebagai fungsi ekologis dan keindahan visual

\section{Fungsi RTH}

Terdapat empat fungsi RTH yaitu fungi ekologi, fungsi sosial budaya, fungsi ekonomi dan fungsi estetika. Fungsi ekologi sebagai pengatur iklim mikri yang berdampak pada lancarnya sirkulasi udara dan air secara alami, sebagai peneduh dan menghasilkan oksigen. Fungsi sosial dan budaya sebagai media komunikasi warga, tempat rekreasi dan wadah objek pendidikan. Fungsi ekonomi RTH memiliki peran dalam kaitannya usaha pertanian dan perkebunan. RTH juga memiliki fungsi estetika yaitu meningkatkan kenyamanan, memperindah lingkungan dan menciptakan suasana serasi (Permen PU No.5, 2008).

\section{Penyediaan RTH di Kawasan Perkotaan}

1. Berdasarkan Luas Wilayah

Ketentuan luas minimal RTH 30\% dari luas wilayah dengan rincian 20\% RTH publik dan 10\% RTH privat diatur dalam Undang-Undang Nomer 26 tahun 2007 tentang Penataan Ruang, Peraturan Menteri Pekerjaan Umum Nomer 5 Tahun 2008 tentang Penyediaan dan Pemanfaatan RTH di Kawasan Perkotaan serta Konferensi Tingkat Tinggi (KTT) Bumi II di Johannesburg-Afrika Selatan yang membahas mengenai upaya untuk mengurangi dampak pemanasan global yang diakibatkan karena karbon dioksida $\left(\mathrm{CO}_{2}\right)$

2. Berdasarkan Jumlah Penduduk

Kaitannya penduduk dengan RTH yaitu penduduk sebagai pengguna dari RTH. Isu utama dalam merancang ruang terbuka adalah memahami kebutuhan dan harapan 
pengguna (Abbasi, 2016). Penyediaan RTH berdasarkan kebutuhan pengguna dapat dilihat pada Tabel 1.

Tabel 1. Penyediaan RTH berdasarkan Jumlah Penduduk

\begin{tabular}{cccccc}
\hline No. & $\begin{array}{c}\text { Unit Lingku- } \\
\text { ngan }\end{array}$ & Tipe RTH & $\begin{array}{c}\text { Luas } \\
\text { minimal } \\
\text { unit }\left(\mathbf{m}^{2}\right)\end{array}$ & $\begin{array}{c}\text { Luas } \\
\text { minimal/ } \\
\text { kapita }\left(\mathbf{m}^{2}\right)\end{array}$ & Radius \\
\hline 1 & 250 jiwa & Taman RT & 250 & 1,0 & $300 \mathrm{~m}$ \\
2 & 2500 jiwa & Taman RW & 1.250 & 0,5 & $1000 \mathrm{~m}$ \\
3 & 30.000 jiwa & Taman Kelurahan & 9.000 & 0,3 & 1 kelurahan \\
4 & 120.000 jiwa & Taman Kecamatan & 24.000 & 0,2 & 1 kecamatan \\
5 & 480.000 jiwa & Pemakaman & disesuaikan & 1,2 & sekota \\
\hline
\end{tabular}

Sumber: Permen PU No.5, 2008

\section{Kesesuaian Lokasi untuk RTH Publik Aktif}

Penentuan lokasi lahan untuk pengembangan Ruang Terbuka Hijau Publik Aktif dengan mempertimbangkan karakteristik Ruang Publik yang diungkapkan oleh Stephen Carr tahun 1992 dalam buku Public Space. Stephen Carr menyebutkan terdapat empat karakteristik dari ruang publi yaitu;

1. Penggunaan Lahan

Penggunaan lahan menentukan baseline layanan maka ditentukan dari tipe tutupan lahan yang sudah ada sehingga akan berpengaruh pada pengambilan keputusan yang benar terhadap infrastruktur hijau (Rottle, 2015).

2. Kepadatan Penduduk

Kepadatan penduduk merupakan komponen dalam menentukan besaran standar dalam perencanaan lingkungan perumahan, tingkat kepadatan penduduk yang tinggi berkaitan dengan sirkulasi udara yang melewati daerah tersebut maka perlu tambahan udara untuk menambah kenyamanan di daerah tersebut (Rottle, 2015)

3. Kelerengan

Dasar dari pertimbangan penggunaan kriteria kemiringan lereng yaitu berkaitan dengan faktor keamanan. Kondisi lahan yang memiliki kelerengan yang curam akan memiliki kemungkinan potensi bencana longsor lebih besar. Lahan yang memiliki kelerengan datar akan mudah diakses dan realisasi karena berhubungan dengan sistem cut and fill serta minimal biaya dalam pembangunannya (Chiara, 1997)

4. Aksesibilitas

Keterkaitan antar jalan akan membentuk suatu integrasi yang berdampak pada tingkat aksesibilitas menuju lokasi yang akan dikunjungi, bahwa jarak terpendek menuju RTH akan mempengaruhi orang untuk datang (Rojas, Páez, 2016).

Selain dari dari empat karakteristik yang diungkapkan Stephen Carr, penentuan kesesuaian lokasi RTH disusun menggunakan parameter bersumber dari buku-buku maupun jurnal. Melalui kajian teoritis tersebut sehingga menghasilkan variabel atau kriteria yang digunakan yaitu kelas penggunaan lahan, tingkat kepadatan penduduk, tingkat kemiringan lereng, dan aksesibilitas. Tabel penentuan parameter dapat dilihat pada Tabel 2.

\section{METODE}

Penelitian ini menggunakan metode deskriptif dengan pendekatan kuantitatif. Penelitian ini mengangkat permasalahan RTH publik aktif yang ada, kemudian dilakukan tindak lanjut atas permasalahn yang ada terkait identifikasi lokasi potensial untuk pemenuhan RTH publik aktif. Teknik pengumpulan pada penelitian ini yaitu koesioner, 
observasi, wawancara dan telaah dokumen. Tujuan dari kuesioner ini untuk memberikan bobot atau percent of influence pada masing-masing variabel, yang digunakan untuk menilai kesesuain lokasi RTH Publik Aktif yang dilakukan dengan analisis AHP

Tabel 2. Penentuan Variabel Kesesuaian RTH Publik

\begin{tabular}{llll}
\hline No & \multicolumn{1}{c}{ Parameter } & \multicolumn{1}{c}{ Beberapa Sumber } \\
\hline \multirow{2}{*}{ 1. } & \multirow{2}{*}{ Penggunaan Lahan } & Miller, 1998 & Achsan, 2015 \\
& & Carr, 1992 & Zhang,2017 \\
& & Rustam Hakim, 2012 & Achsan, 2015 \\
& Spreiregen, 1965 & Kabisch, 2015 \\
2. & \multirow{2}{*}{ Kepadatan Penduduk } & Carr, 1992 & Achsan, 2015 \\
& & Miller, 1998 & Humaida, 2016 \\
& & Spreiregen, 1965 & Russ, 2009 \\
3. & \multirow{2}{*}{ Kelerengan } & Carr, 1992 & Achsan, 2015 \\
& & Miller, 1998 & \\
4. & \multirow{2}{*}{ Aksesibilitas } & Carr, 1992 & Achsan, 2015 \\
& & Edy,2009 & Fan, Xu, Yue, \& Chen, 2017 \\
\hline
\end{tabular}

Sumber: Hasil Analisis, 2018

. Bobot atau percent of influence digunakan untuk memberi bobot pada analisis weighted overlay, untuk mendapatkan peta kesesuaian lokasi RTH publik aktif. Metode pengambilan sampel pada penelitian ini menggunakan metode non probability sampling, penentuan sempel pada kuesioner ditetapkan berdasarkan keahlian dibidang kajian penelitian, terdapat empat sempel yaitu Dinas Lingkungan Hidup, Bappelitbangda, Dinas Pekerjaan Umum dan Penataan Ruang, serta ahli Landscape Architecture. Analisis AHP dilakukan dengan dilakukan dengan cara perbandingan berpasangan, yaitu membandingkan kriteria-kriteria penelitian dalam satu tabel. Tabel perbandingan berpasangan dapat dilihat pada tabel 3 .

Tabel 3. Tabel Perbandingan Berpasangan

\begin{tabular}{ccccccccc}
\hline \multicolumn{5}{c}{ Kriteria } & \multicolumn{5}{c}{ Penilaian } & Kriteria \\
\hline kemiringan lereng & 9.7 .5 .3 & .1. & 3.5 .7 .9 & kepadatan \\
kemiringan lereng & 9.7 .5 .3 & .1. & 3.5 .7 .9 & Peggunaan lahan \\
kemiringan lereng & 9.7 .5 .3 & .1. & 3.5 .7 .9 & aksesibilitas \\
Kepadatan & 9.7 .5 .3 & .1. & 3.5 .7 .9 & Penggunaan lahan \\
Kepadatan & 9.7 .5 .3 & .1. & 3.5 .7 .9 & aksesibilitas \\
Penggunaan lahan & 9.7 .5 .3 & .1. & 3.5 .7 .9 & aksesibilitas \\
\hline
\end{tabular}

Sumber: Hasil Analisis Penulis, 2018

Setelah matrik perbandingan antar elemen-elemen didapat maka dilakukan sintesa dengan menjumlah setiap kolom.Setelah itu angka pada setiap sel dibagi dengan jumlah kolom pada deret total, sehingga menghasilkan matriks yang telah dinormalkan dengan nilai CR $<10 \%$ yang artinya nilai diterima. Nilai keempat variabel dari hasil AHP dapat dilihat pada tabel 4 .

Tabel 4. Nilai Percent of Influences hasil AHP

\begin{tabular}{cc}
\hline Variabel & Percent Of Influences(Bobot) \\
\hline Kemiringan Lereng & $18 \%$ \\
Kepadatan & $35 \%$ \\
Penggunaan Lahan & $25 \%$ \\
Aksesibilitas & $22 \%$ \\
\hline
\end{tabular}

Sumber: Hasil Analisis Penulis, 2018 
Besaran percent of influences berasal dari penilaian Bappelitbangda Kota Salatiga, Dinas Lingkungan Hidup Kota Salatiga, Dinas Pekerjaan Umum dan Penataan Ruang Kota Salatiga dan Ahli landcscap Architectur. Percent of influence akan diolah dalam analisis weighted overlay

\section{Teknik Analisis}

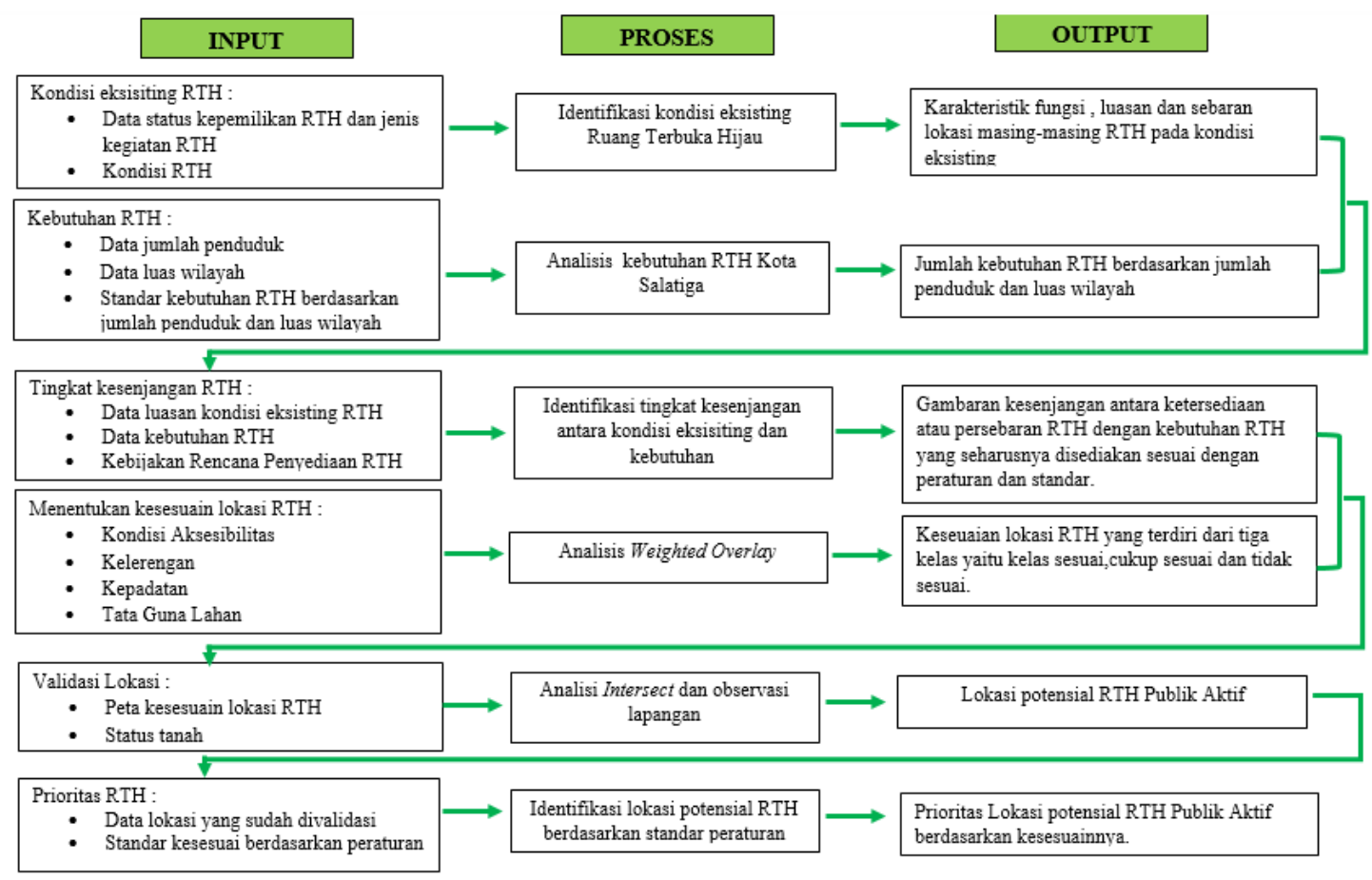

Sumber: Hasil Analisis Penulis, 2018

Gambar 1. Kerangka Analisis

\section{Temuan dan Analisis}

\section{Identifikasi Kondisi Eksisting RTH di Kota Salatiga}

1. Identifikasi Kondisi Eksisting RTH Publik

Berdasarkan data eksisting, RTH yang ada di Kota Salatiga digolongkan menjadi: Perlindungan bawahannya, sempadan sungai, sempadan mata air, sempadan waduk atau embung, sempadan SUTET, Taman Kota atau Hutan Kota, Jalur Hijau, Tempat Pemakaman Umum dan Pariwisata.Pada kondisi eksisiting luas RTH Publik memiliki prosentase sebesar 5,61\%, mengalami kenaikan sebesar $1,1 \%$ dari tahun 2010 yang sebelumnya hanya memiliki nilai sebesar 4,6\%. Distribusi prosentase RTH dapat dilihat pada Gambar 2 dan persebaran RTH Publik dapat dilihat pada gambar 3 (a):

2. Identifikasi Kondisi Eksisting RTH Publik

Berdasarkan Kondisi eksisting RTH Publik yang sudah dijelaskan pada bab sebelumnya, RTH Publik Aktif berupa taman memiliki luas $39,852 \mathrm{~m}^{2}$ atau persentasenya sebesar $0,7 \%$. Data tersebut menunjukan nilai luas taman kota dan hutan kota, jika dirinci lebih detail kondisi eksisiting taman Kota Salatiga hanya memiliki luas sebesar 4,68 hektar dengan prosentase $0,08 \%$, rincian luas taman dapat dilihat pada tabel 5 sebagai berikut: 


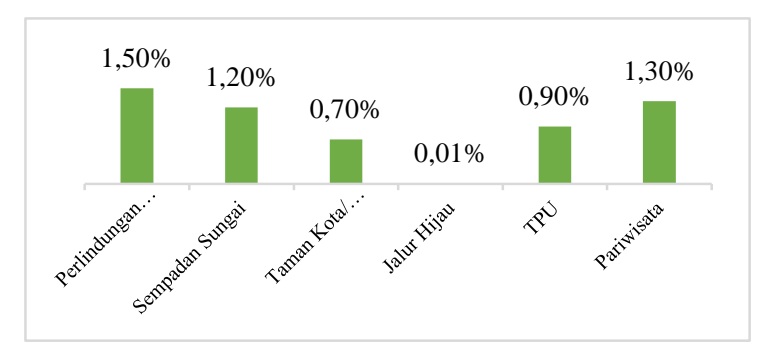

Sumber: Bappelitbangda Kota Salatiga, 2013

Gambar 2. Distribusi Prosentase RTH Publik Kota Salatiga

Tabel 5. Kondisi Eksisiting Taman di Kota Salatiga

\begin{tabular}{|c|c|c|c|c|}
\hline No & Kecamatan & Kelurahan & Taman & Luas $\left(\mathrm{m}^{2}\right)$ \\
\hline \multirow{3}{*}{1} & \multirow{3}{*}{ Sidorejo } & \multirow{3}{*}{ Blotongan } & $\begin{array}{l}\text { Tugu Batas Kota Utara jalan Fatmawati } \\
\text { (sebelah kiri, jalan arah kota Salatiga) }\end{array}$ & 81,38 \\
\hline & & & $\begin{array}{l}\text { Tugu Batas Kota Utara jalan Fatmawati } \\
\text { (sebelah kiri, jalan arah kota Salatiga) }\end{array}$ & 157 \\
\hline & & & Jalan Fatmawati & 206,03 \\
\hline \multirow{14}{*}{2} & \multirow{14}{*}{ Tingkir } & \multirow{8}{*}{ Sidorejo Lor } & Taman Jalan Seruni & 233,81 \\
\hline & & & Depan Kantor Polrees/Taman BMPD & 353,79 \\
\hline & & & Bunderan Tugu Jam Taman Sari & 200,96 \\
\hline & & & Perempatan Penjara & 315,8 \\
\hline & & & Pertigaan Diponegoro (Depan BTN) & 16,12 \\
\hline & & & Jalan Diponegoro & 478 \\
\hline & & & Pertigaan Kauman sampai Penjara & 510 \\
\hline & & & Selasar Kartini & 1232,5 \\
\hline & & \multirow{3}{*}{ Pulutan } & Depan Kantor Samsat & 108,78 \\
\hline & & & Depan IPHI & 678,7 \\
\hline & & & Perempatan Pasar Sapi & 23,91 \\
\hline & & \multirow{2}{*}{ Gendongan } & Tugu PKK PasarSapi & 23,91 \\
\hline & & & pertigaan mrican & 14,4 \\
\hline & & $\begin{array}{l}\text { Sidorejo } \\
\text { Kidul }\end{array}$ & Taman Tingkir & 11000 \\
\hline \multirow{3}{*}{3} & \multirow{3}{*}{ Argomulyo } & Ledok & $\begin{array}{l}\text { Tugu Atlit (Pertigaan ABC) } \\
\text { Jalan Jendral Sudirman }\end{array}$ & $\begin{array}{r}42 \\
634.85\end{array}$ \\
\hline & & Kumpulrejo & Taman Bendosari & 23.000 \\
\hline & & \multirow[t]{3}{*}{ Cebongan } & Taman Batas Kota Jalan Soekarno Hatta & 838,8 \\
\hline \multirow{9}{*}{4} & \multirow{9}{*}{ Sidomukti } & & Stadion Kridanggo & 85,9 \\
\hline & & & Jalan tentara pelajar & 40,48 \\
\hline & & \multirow{3}{*}{ Mangunsari } & Depan SDN 02 Kalicacing & 217,65 \\
\hline & & & Samping Masjid Pancasila & 38,4 \\
\hline & & & Jalan Sukowati & 450 \\
\hline & & \multirow{4}{*}{ Kalicacing } & Pertigaan Jalan Adisucipto Pancasila & 51,5 \\
\hline & & & Depan warung prasmanan Pancasila & 511,64 \\
\hline & & & Lapangan Pancasila & 4878,14 \\
\hline & & & Samping Diknas & 362 \\
\hline \multicolumn{4}{|c|}{ Total (m2) } & 46786,45 \\
\hline \multicolumn{4}{|c|}{ Total (ha) } & 4,68 \\
\hline \multicolumn{4}{|c|}{ Luas Wilayah Kota Salatiga (ha) } & 5678 \\
\hline \multicolumn{4}{|c|}{ Persentase $(\%)$} & $0,08 \%$ \\
\hline
\end{tabular}

Sumber: Dinas Lingkungan Hidup, 2017

RTH publik aktif yang seharusnya berfungsi sebagai tempat untuk bersosialisasi, olahraga dan bermain, pada kondisi eksisiting RTH publik yang ada tidak memenuhi standar taman dari kualitas dan kuantitas berdarkan Peraturan Menteri Pekerjaan Umum Nomor 5 Tahun 2008 tentang pedoman penyediaan RTH di Kawasan Perkotaan. 
Berdasarkan data yang ada, dari 30 titik lokasi taman hanya ada 3 taman yang memenuhi standar RTH publik aktif yaitu alun-alun Pancasila, Taman Tingkir dan Taman Bendosari. RTH publik aktif yang pertama yaitu alun-alun Pancasila yang berada di Kecamatan Sidomukti berada di kawasan strategis Kota Salatiga. Peta persebaran RTH Publik Aktif dapat dilihat pada gambar 3(b)
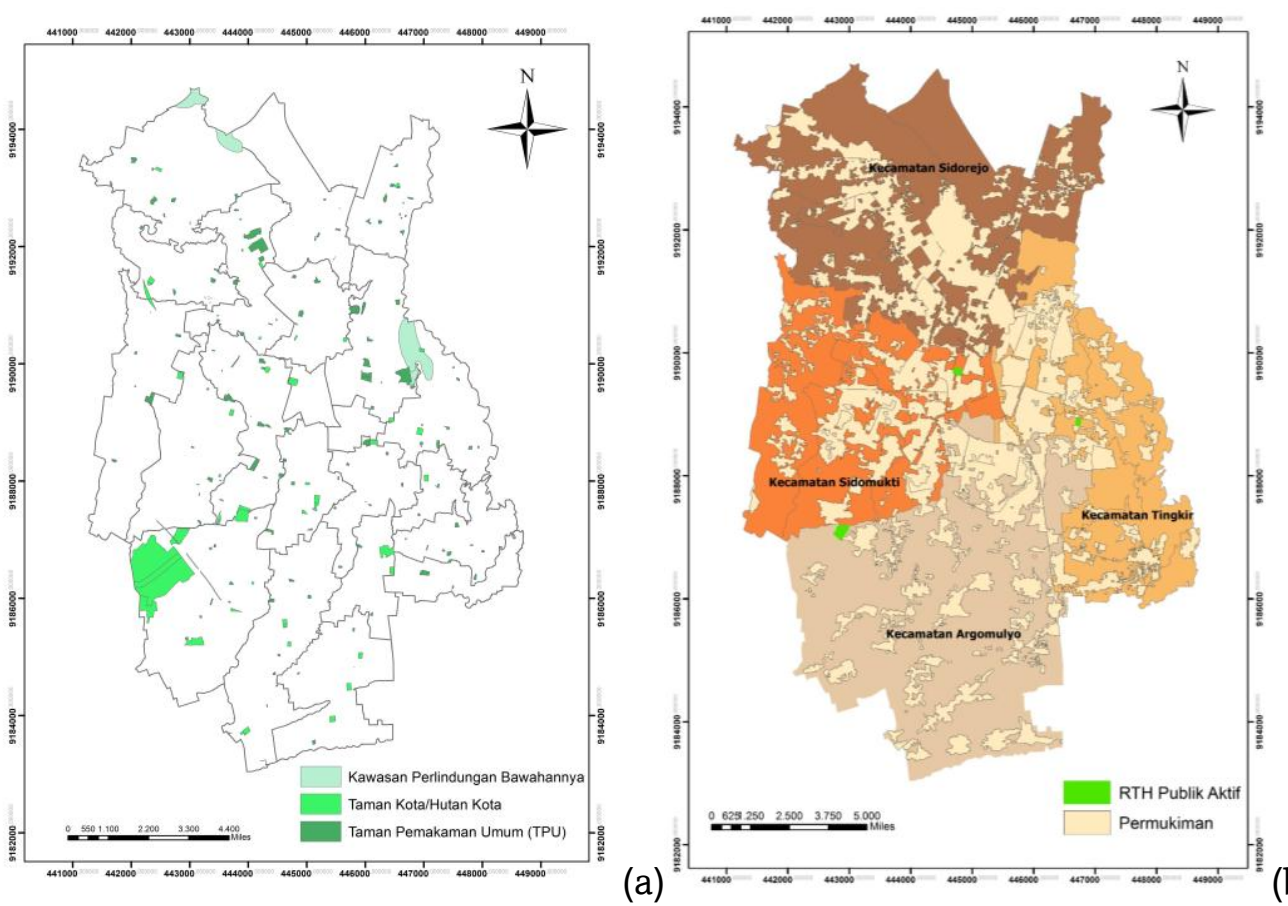

Sumber: Hasil Analisis Penulis, 2018

Gambar 3. (a) Persebaran RTH Publik (b) Persebaran RTH Publik Aktif

\section{Analisis Kebutuhan RTH di Kota Salatiga}

1. Penyediaan RTH berdasarkan Luas Wilayah

Kebutuhan RTH berdasarkan luas wilayah mengacu pada ketentuan standar minimal luas RTH sebesar 30\% dari luas wilayah. Kota Salatiga memiliki luas wilayah sebesar 5.678 hektar artinya ketentuan luas minimal RTH 30\% yaitu sebesar 1703,4 hektar

2. Penyediaan RTH berdasarkan Jumlah Penduduk

Kebutuhan RTH berdasarkan jumlah penduduk dilakukan dengan mengolah data jumlah penduduk 5 tahun terakhir yaitu tahun 2012, 2013, 2014, 2015 dan 2016 untuk dijadikan dasar dalam proyeksi penduduk ditahun 2017, 2022, 2027 dan 2032. Data jumlah penduduk diambil dari Kota Salatiga dalam Angka yang bersumber dari BPS Kota Salatiga. Data jumlah penduduk kemudian diolah menggunakan tabel perhitungan kebutuhan RTH berdasarkan jumlah penduduk sesuai Peraturan Menteri Pekerjaan Umum Nomer 5 tahun 2008. Dalam pedoman penyediaan RTH di Kawasan Perkotaan besar kebutuhan RTH seluas $20 \mathrm{~m}^{2}$ perjiwa. Berikut perhitungan kebutuhan RTH berdasarkan jumlah penduduk dapat dilihat pada tabel 6 
Tabel 6. Perhitungan Kebutuhan RTH berdsarkan Jumlah Penduduk

\begin{tabular}{|c|c|c|c|c|c|c|c|c|c|c|}
\hline \multicolumn{2}{|c|}{ Jumlah Penduduk } & \multicolumn{3}{|c|}{ Taman RT } & \multicolumn{2}{|c|}{ Taman RW } & \multicolumn{2}{|c|}{ Taman Kelurahan } & \multicolumn{2}{|c|}{ Taman Kecamatan } \\
\hline Tahun & Jiwa & $\begin{array}{c}250 \\
\text { jiwa/ } \\
\text { unit } \\
\left(\mathrm{m}^{2}\right)\end{array}$ & $\begin{array}{c}1 \\
\text { kapi }\end{array}$ & $\left(\mathrm{m}^{2}\right)$ & $\begin{array}{r}1250 \\
\text { jiwa/ } \\
\text { unit } \\
\left(\mathrm{m}^{2}\right)\end{array}$ & $\begin{array}{c}0,5 \mathrm{~m}^{2} / \\
\text { kapita } \\
\left(\mathrm{m}^{2}\right)\end{array}$ & $\begin{array}{c}9000 \\
\text { jiwa/ } \\
\text { unit } \\
\left(\mathrm{m}^{2}\right)\end{array}$ & $\begin{array}{c}0,3 \mathrm{~m}^{2} / \\
\text { kapita } \\
\left(\mathrm{m}^{2}\right)\end{array}$ & $\begin{array}{c}24000 \\
\text { jiwa/ } \\
\text { unit } \\
\left(\mathrm{m}^{2}\right)\end{array}$ & $\begin{array}{r}0,2 \mathrm{~m}^{2} / \\
\text { kapita } \\
\left(\mathrm{m}^{2}\right)\end{array}$ \\
\hline 2016 & 186316 & 745 & 18 & & 149 & 93158 & 21 & 55894,8 & 8 & 37263,2 \\
\hline 2021 & 186842 & 747 & 18 & & 149 & 93421 & 21 & 56052,6 & 8 & 37368,4 \\
\hline 2026 & 201998 & 808 & 20 & & 162 & 100999 & 22 & 60599,4 & 8 & 40399,6 \\
\hline 2031 & 217155 & 869 & 21 & & 174 & 108578 & 24 & 65146,5 & 9 & 43431 \\
\hline 2036 & 232311 & 929 & 23 & & 186 & 116155 & 26 & 69693.3 & 10 & 46462,2 \\
\hline $\begin{array}{c}\text { Pemaka } \\
\text { man }\end{array}$ & \multicolumn{3}{|c|}{ Taman Kota } & \multicolumn{2}{|c|}{$\begin{array}{c}\text { Hutan } \\
\text { Kota }\end{array}$} & $\begin{array}{c}\text { Fungsi } \\
\text { tertentu }\end{array}$ & \multicolumn{2}{|c|}{ luas Total } & \multirow{2}{*}{\multicolumn{2}{|c|}{$\begin{array}{c}\text { Prosentase } \\
\text { terhadap luas } \\
\text { Wilayah }\end{array}$}} \\
\hline $\begin{array}{c}1,2 \mathrm{~m}^{2} / \\
\text { kapita } \\
\left(\mathrm{m}^{2}\right)\end{array}$ & $\begin{array}{c}144000 \\
\text { jiwa/ } \\
\text { unit }\left(\mathrm{m}^{2}\right)\end{array}$ & \multicolumn{2}{|c|}{$\begin{array}{c}0,3 \mathrm{~m}^{2} / \\
\text { kapita }\left(\mathrm{m}^{2}\right)\end{array}$} & \multicolumn{2}{|c|}{$\begin{array}{c}4 \mathrm{~m}^{2} / \\
\text { kapita } \\
\left(\mathrm{m}^{2}\right)\end{array}$} & $\begin{array}{c}12,5 \mathrm{~m}^{2} / \\
\text { kapita }\left(\mathrm{m}^{2}\right)\end{array}$ & $\mathrm{m}^{2}$ & $\mathrm{Ha}$ & & \\
\hline 223579,2 & 1 & \multicolumn{2}{|c|}{55894,8} & \multicolumn{2}{|c|}{745264} & 2328950 & 3.726 .320 & 372,63 & \multicolumn{2}{|c|}{$6,56 \%$} \\
\hline 224210,4 & 1 & \multicolumn{2}{|c|}{56052,6} & \multicolumn{2}{|c|}{747368} & 2335525 & 3.736 .840 & 373,68 & \multicolumn{2}{|c|}{$6,58 \%$} \\
\hline 242397,6 & 1 & \multicolumn{2}{|c|}{60599,4} & \multicolumn{2}{|c|}{807992} & 2524975 & 4.039 .960 & 403,91 & \multicolumn{2}{|c|}{$7,11 \%$} \\
\hline 260586 & 2 & \multicolumn{2}{|c|}{65146,5} & \multicolumn{2}{|c|}{868620} & 2714437 & 4.343 .100 & 434,31 & \multicolumn{2}{|c|}{$7,65 \%$} \\
\hline 278773.2 & 2 & \multicolumn{2}{|c|}{69693,3} & \multicolumn{2}{|c|}{929244} & 2903888 & 4.646 .220 & 464,62 & \multicolumn{2}{|c|}{$8,18 \%$} \\
\hline
\end{tabular}

Sumber: Hasil Analisis Penulis, 2018

Perhitungan RTH berdasarkan jumlah penduduk pada tabel 5 dilakukan dengan menghitung RTH Publik dengan tipe taman skala RT hingga kota, pemakaman, hutan kota dan fungsi tertentu seperti jalur hijau, sempadan rel kereta api dan jalur hijau. Sehingga untuk menghitung RTH Publik aktif berupa taman maka perhitungan kebutuhan RTH menjadi seluas $2,3 \mathrm{~m}^{2}$ perjiwa. Perhitungan tersebut akan menghasilkan rincian perhitungan yang berada pada tabel 7 sebagai berikut :

Tabel 7. Perhitungan Kebutuhan RTH Publik Aktif Berdasarkan Jumlah Penduduk

\begin{tabular}{|c|c|c|c|c|c|c|c|}
\hline No & $\begin{array}{l}\text { Tipe } \\
\text { RTH }\end{array}$ & $\begin{array}{c}\text { Unit } \\
\text { Lingkungan } \\
\text { (jiwa) }\end{array}$ & $\begin{array}{c}\text { luas } \\
\text { minimal } \\
\text { jiwa/unit } \\
\left(\mathrm{m}^{2}\right)\end{array}$ & $\begin{array}{c}\text { luas } \\
\text { minimal } \\
\mathrm{m}^{2} / \mathrm{kapita} \\
\left(2,3 \mathrm{~m}^{2}\right)\end{array}$ & $\begin{array}{c}\text { Jumlah } \\
\text { penduduk }\end{array}$ & $\begin{array}{l}\text { Perhitungan } \\
\text { (unit) }\end{array}$ & luas \\
\hline 1 & $\begin{array}{l}\text { Taman } \\
\text { RT }\end{array}$ & 250 & 250 & 1 & 186316 & 745 & 186316 \\
\hline 2 & $\begin{array}{l}\text { Taman } \\
\text { RW }\end{array}$ & 2500 & 1.250 & 0,5 & & 149 & 93158 \\
\hline 3 & $\begin{array}{l}\text { Taman } \\
\text { Kelurahan }\end{array}$ & 30.000 & 9.000 & 0,3 & & 21 & 55894,8 \\
\hline 4 & $\begin{array}{l}\text { Taman } \\
\text { Kecamatan }\end{array}$ & 120.000 & 24.000 & 0,2 & & 8 & 37263,2 \\
\hline 5 & $\begin{array}{l}\text { Taman } \\
\text { Kota }\end{array}$ & 480.000 & 144000 & 0,3 & & 1 & 55894,8 \\
\hline \multicolumn{7}{|c|}{ Total $\left(\mathrm{m}^{2}\right)$} & 428526,8 \\
\hline \multicolumn{7}{|c|}{ Total (ha) } & 42,85 \\
\hline \multicolumn{7}{|c|}{ Luas wilayah (ha) } & 5678 \\
\hline \multicolumn{7}{|c|}{ Persentase terhadap luas wilayah (\%) } & $0,76 \%$ \\
\hline
\end{tabular}

Sumber: Hasil Analisis Penulis, 2018

\section{Analisis Tingkat Kesenjangan RTH di Kota Salatiga}

1. Kesenjangan berdasarkan Luas Wilayah

Berdasarkan uraian prosentase RTH publik pada kondisi eksisiting menunjukan kondisi RTH Publik Salatiga masih kurang, besaran RTH publik baru sebesar 5,6\%, artinya kebutuhan RTH Publik berdasarkan luas wilayah kekurangan $14,4 \%$, sesuai standar 
Peraturan Menteri Pekerjaan Umum nomer 5 tahun 2008 besaran luas RTH Publik minimal $20 \%$ dari luas wilayah.

. Tabel 8. Kesenjangan Penyediaan RTH berdasarkan Luas Wilayah

\begin{tabular}{ccrrc}
\hline $\begin{array}{c}\text { Luas Wilayah } \\
\text { (ha) }\end{array}$ & Ketentuan & $\begin{array}{c}\text { Kebutuhan RTH } \\
\text { (ha) }\end{array}$ & $\begin{array}{c}\text { Kondisi } \\
\text { Eksisiting (ha) }\end{array}$ & $\begin{array}{c}\text { Kesenjangan } \\
\text { (ha) }\end{array}$ \\
\hline 5678 & RTH Publik 20\% & 1135,6 & $318,6(5,6 \%)$ & $817(14,4 \%)$ \\
& RTH Privat 10\% & 567,8 & $365(6,4 \%)$ & $202,8(3,6 \%)$ \\
\hline
\end{tabular}

Sumber: Hasil Analisis Penulis, 2018

2. Kesenjangan berdasarkan Jumlah Penduduk

Kesenjangan perhitungan kebutuhan RTH berdasaran jumlah penduduk dilakukan dengan menghitung kesenjangan RTH dan RTH Publik. Kedua perhitungan kesenjangan mengacu pada pedoman Peraturan Menteri Pekerjaan Umum Nomer 5 tahun 2008 yang mengatur kebutuhan RTH, yang membedakan yaitu pada kesenjangan RTH Publik termuat semua tipe RTH Publik seperti tipe taman skala RT hingga kota ,pemakaman, hutan kota dan untuk fungsi-fungsi tertentu. Sedangkan pada perhitungan kesenjangan RTH taman hanya dilakukan perhitungan tipe RTH taman skala RT, RW, Kelurahan, Kecamatan dan Kota. Untuk Kebutuhan RTH publik memiliki luas minimal $20 \mathrm{~m}^{2}$ perjiwa sedangkan untuk kebutuhan RTH Taman memiliki luas minimal 2,3 $\mathrm{m}^{2}$ perjiwa. Perhitungan kesenjangan antara kebutuhan RTH dan kondisi eksisiting dapat dilihat pada tabel 9 :

Tabel 9. Kesenjangan Penyediaan RTH berdasarkan Jumlah Penduduk

\begin{tabular}{lcccccc}
\hline & $\begin{array}{c}\text { Kebutuhan } \\
\text { RTH Publik }\end{array}$ & $\begin{array}{c}\text { Kondisi Eksisiting } \\
\text { RTH Publik }\end{array}$ & $\begin{array}{c}\text { Kesenjangan } \\
\text { RTH Publik }\end{array}$ & $\begin{array}{c}\text { Kebutuhan } \\
\text { RTH Taman }\end{array}$ & $\begin{array}{c}\text { Kondisi eksisiting } \\
\text { RTH Taman }\end{array}$ & $\begin{array}{c}\text { Kesenjangan } \\
\text { RTH Taman }\end{array}$ \\
\hline (Ha) & 372,63 & 318,6 & 54,03 & 42,85 & 4,68 & 38,17 \\
(\%) & $6,56 \%$ & $5,6 \%$ & $0,96 \%$ & $0,76 \%$ & $0,08 \%$ & $0,7 \%$ \\
\hline
\end{tabular}

Sumber: Hasil Analisis Penulis, 2018

\section{Analisis Kesesuaian Lokasi RTH}

Data yang diolah dalam metode weighted overlay berupa shp kelerengan, penggunaan lahan, jalan, dan kepadatan. Kriteria didapat dari hasil penelitian sebelumnya dan hasil dari teori yang ada dalam buku. Nilai skor didapat dari diskusi dengan ahli landscape architecture dan nilai bobot atau percent of influences didapat dari analisis AHP yang peneliti lakukan. Data yang diolah dalam prosses weighted overlay dapat dilihat pada tabel 10 sebagai berikut

Tabel 10. Kriteria Kesesuaian Lokasi Potensial RTH PublikAktif diKota Salatiga

\begin{tabular}{cclcc}
\hline Parameter & Kriteria & \multicolumn{1}{c}{ Sub Kriteria } & Skor & Bobot \\
\hline Penggunaan & Kelas & Ruang Terbuka Hijau & 3 & $\mathbf{2 5 \%}$ \\
Lahan & Penggunaan & Perdagangan & 2 & \\
& Lahan & Permukiman & 3 & \\
& TPA & 1 & \\
& Militer & 1 & \\
& Pertanian Lahan Kering & 1 & \\
& Sawah Irigasi & 1 & \\
& Sawah Non Irigasi & 1 & \\
& Pemakaman & 1 & \\
& Fasos & 1 & \\
& Industri & 1 & \\
& Pendidikan & 1 & \\
& Kesehatan & 1 & \\
& & Perkebunan &
\end{tabular}




\begin{tabular}{|c|c|c|c|c|}
\hline Parameter & Kriteria & Sub Kriteria & Skor & Bobot \\
\hline & & Perkantoran & 1 & \\
\hline Kemiringan & Tingkat & Kemiringan $<2 \%$ (datar) & 3 & $18 \%$ \\
\hline \multirow[t]{4}{*}{ Lereng } & kemiringan & Kemiringan 2-8\% (landai) & 3 & \\
\hline & lereng & Kemiringan $8-30 \%$ (miring) & 2 & \\
\hline & & Kemiringan $30-40 \%$ (terjal) & 1 & \\
\hline & & Kemiringan $>40 \%$ (sangat terjal) & 1 & \\
\hline Kepadatan & Tingkat & Sangat Tinggi ( $>400 \mathrm{jiwa} / \mathrm{ha})$ & 3 & $35 \%$ \\
\hline \multirow[t]{3}{*}{ Penduduk } & kepadatan & Tinggi (200-400 jiwa/ha) & 3 & \\
\hline & & Sedang(151-200 jiwa/ha) & 2 & \\
\hline & & Rendah (<150 jiwa/ha) & 1 & \\
\hline \multirow[t]{3}{*}{ Aksesibilitas } & Jarak terhadap & Jarak 200 m dari jalan & 3 & $22 \%$ \\
\hline & jalan & Jarak 400 m dari jalan & 2 & \\
\hline & & Jarak $>400$ m dari jalan & 1 & \\
\hline
\end{tabular}

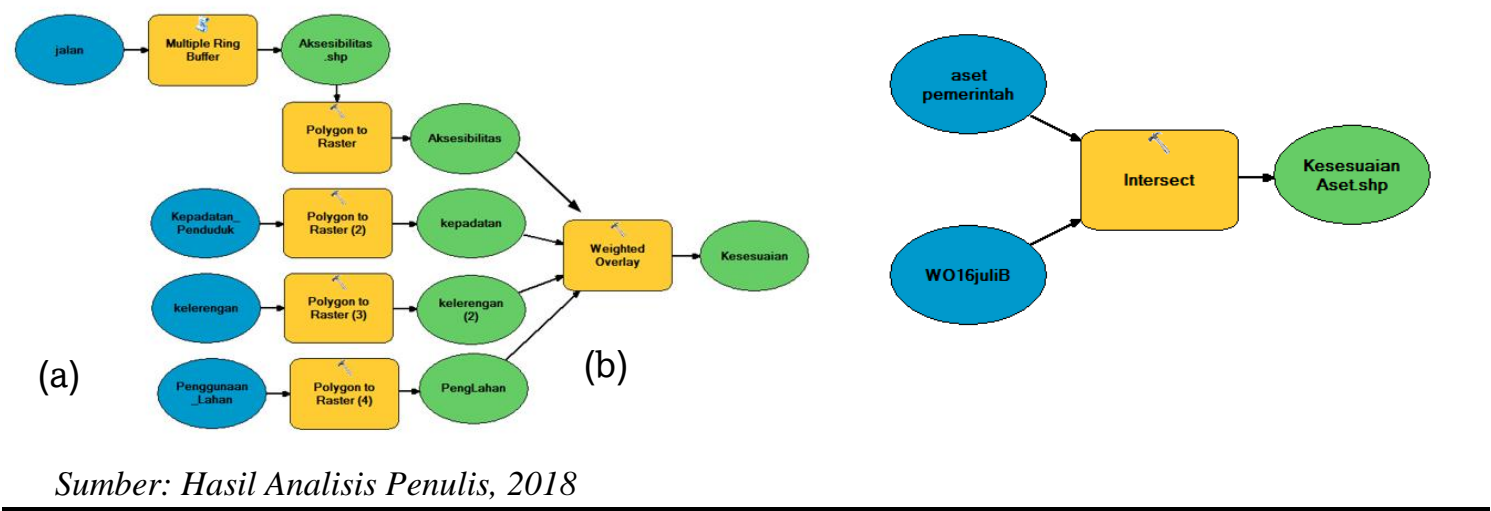

\section{Gambar 4. (a) Proses Weighted Overlay (b) Proses Intersect}

Secara berurutan proses weighted overlay dapat dilihat pada gambar 4 (a), Hasil analisis weighted overlay berupa peta kesesuaian yang menghasilkan tiga kelas kesesuaian yaitu kelas sesuai, cukup sesuai dan tidak sesuai dapat dilihat pada gambar 5 (a). Hasil dari weighted overlay terlihat bahwa kelas kesesuaian cukup sesuai memiliki luas terbesar diantara dua kelas lainnya, masing-masing kelas kesesuaian memiliki luas sebagai berikut :

1. Kelas tidak sesuai, memiliki luas 712,32 hektar

2. Kelas cukup sesuai , memiliki luas 3365,26 hektar

3. Kelas sesuai, memiliki luas 1483,32 hektar

\section{Validasi Lokasi}

Sehubungan dengan realisasi kemungkinan lokasi yang terpilih, karena salah satu hambatan dalam mewujudkan RTH yaitu faktor status kepemilikan lahan. Status kepemilikan lahan merupakan salah satu faktor penghambat dalam realisasi Ruang Terbuka Hijau Publik Aktif, hal ini berkaitan dengan minimnya lahan, keterbatasan anggaran dan sulitnya pembebasan lahan (Ekawati, 2016). Analisis ini dilakukan dengan menggunakan peta kesesuaian lokasi RTH diintersect dengan shp aset pemerintah kota salatiga. Untuk mengetahui proses analisis intersect secara berurutan maka langkah selanjutnya membuat model builder pada software ArcGIS dilihat pada gambar 4(b). 

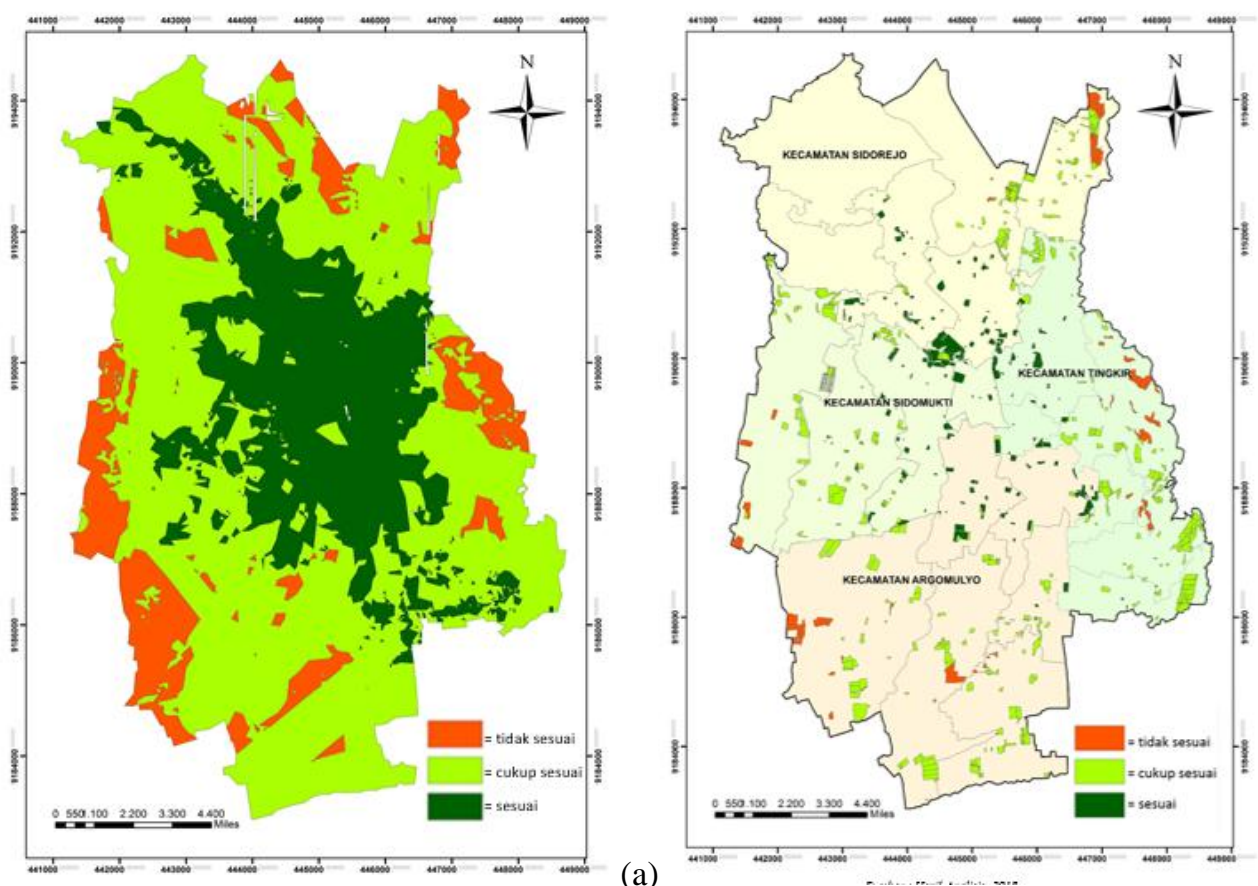

(b)

Sumber: Hasil Analisis Penulis, 2018

Gambar 5. (a) Peta Kesesuaian Lokasi (b) Peta Kesesuaian Lokasi dengan Aset Pemerintah

Hasil analisisi ini berupa titik lokasi lahan ilik pemerintah yang memiliki tiga kelas kesesuaian, dapat dilihat pada gmbar 5(b). Lokasi aset pemerintah yang memiliki kelas sesuai dan cukup sesuai kemudian akan divalidasi dengan cara observasi. Tujuan dari observasi ini melihat kondisi eksisting berupa fungsi maupun Rencana Tata Ruang Wilayah (RTRW) Kota Salatiga. Terdapat 584 titik lokasi yang memiliki kelas cukup sesuai dan 348 titik kelas sesuai. Hasil observasi berupa lokasi yang dianggap memiliki kesesuaian baik dalam fungsi kegiatan saat ini maupun dengan RTRW Kota Salatiga. Lokasi yang terpilih merupakan hasil pertimbangan dengan ketentuan Zoning Text Kota Salatiga. Penggunaan lahan untuk kepentingan umum berupa RTH Publik Aktif taman diizinkan disegala jenis penggunaan lahan kecuali pada tanaman pangan dan perikanan budidaya air tawar. Hasil observasi terkait RTRW dan kondisi eksisting menghasilkan 29 titik lahan yang potensial untuk dikembangkan menjadi RTH Publik Aktif dapat dilihat pada tabel 11

Tabel 11. Lokasi Potensial untuk Pemenuhan RTH Publik Aktif

\begin{tabular}{clrll}
\hline No & & Lokasi & Luas & \multicolumn{1}{c}{ RTRW } \\
\hline 1 & Suko & 8.114 & Perdagangan dan Jasa & Eks Terminal Bus Salatiga \\
2 & Bugel & 22.550 & RTH & Tanah Sawah Padi \\
3 & Bugel & 3.012 & RTH & Tanah Sawah Padi \\
4 & Bugel & 1.353 & RTH & Tanah Sawah Padi \\
5 & Bugel & 5.288 & RTH & Tanah Sawah Padi \\
6 & Bugel & 8.500 & RTH & Tanah Sawah Padi \\
7 & Bugel & 7.106 & RTH & Tanah Sawah Padi \\
8 & Bugel & 5.767 & Taman Kota/Hutan Kota & Lapangan \\
9 & Kauman Kidul & 4.774 & Perumahan Kepadatan Rendah & Lapangan \\
10 & Bugel & 2.714 & RTH & Tanah Sawah Padi \\
11 & Bugel & 3.218 & RTH & Tanah Sawah Padi \\
12 & Dukuh & 6.954 & Perumahan Kepadatan Rendah & Tegalan \\
13 & Dukuh & 6954 & Perumahan Kepadatan Rendah & Tegalan \\
14 & Dukuh & 10.825 & Perumahan Kepadatan Rendah & Lapangan Bola \\
\hline
\end{tabular}




\begin{tabular}{clrll}
\hline No & \multicolumn{1}{c}{ Lokasi } & Luas & \multicolumn{1}{c}{ RTRW } & Keterangan \\
\hline 15 & Dukuh & 5.739 & Taman Kota/Hutan Kota & Lapangan Sepak Bola \\
16 & Kecandran & 1.371 & Taman Kota/ Hutan Kota & Tanah tanaman rupa-rupa \\
17 & Mangunsari & 5.322 & Taman Kota/Hutan Kota & Tanah tanaman rupa-rupa \\
18 & Noborejo Dukuh Brajan & 5.470 & Taman Kota & Lapangan Sepak Bola \\
& & & & Tegalan \\
19 & Noborejo Dukuh Brajan & 5.290 & Tamana Kota / Hutan Kota & Lapangan Sepak Bola \\
20 & Noborejo Dukuh Nobo & 8.740 & Taman Kota & Lapangan Sepak Bola \\
21 & Tegalrejo Dukuh Bulu & 9.670 & Taman Kota/Hutan Kota & Tanah Pertanian \\
22 & Tegalrejo Dukuh Bulu & 2.329 & Taman Kota/Hutan Kota & Tumpangsari \\
23 & Tegalrejo Dukuh Bulu & 9.670 & Taman Kota/Hutan Kota & Lapangan Sepak Bola \\
24 & Tegalrejo Dukuh Bulu & 2.392 & Taman Kota & Lapangan Sepak Bola \\
25 & Tegalrejo Jl. Ngadisa & 2.913 & Perumahan Kepadatan Tinggi & Lapangan Sepak Bola \\
26 & Dukuh Kenteng & 13.392 & RTH & Tegalan \\
27 & Dukuh Kenteng & 11.202 & RTH & Tegalan \\
28 & Ledok & 8.015 & Taman Kota/ Hutan Kota & Lapangan Sepak Bola \\
29 & Sidorejo Kidul, Dukuh & 2.153 & Taman Kota/Hutan Kota & Lapangann Sepak Bola \\
& Gunungsari & & \\
\hline
\end{tabular}

Sumber: Hasil Analisis Penulis, 2018

\section{Prioritas Lokasi RTH Publik Aktif}

Hasil analisis terkait status tanah milik pemerintah yang sudah divalidasi terkait RTRW dan kondisi eksisiting kemudian akan diprioritaskan atau diurutkan berdasarkan tingkat kepentingan yang ada dilapangan saat ini. Berdasarkan dari uraian identifikasi kondisi eksisiting RTH Publik aktif bahwa saat ini RTH Publik aktif baru tersebar di tiga kecamatan yaitu di Kecamatan Tingkir berupa taman Tingkir, di Kecamatan Sidomukti yaitu lapangan Pancasila dan di Kecamatan Argomulyo berupa Taman Bendosari. Satu kecamatan yang belum memiliki RTH Publik Aktif yaitu di Kecamatan Sidorejo, sehingga banyak dikeluhkan masyarakat kesulitan dalam menjangkau RTH Publik Aktif. Terpilih satu lokasi yang menjadi prioritas utama yaitu berada di Suko, Kelurahan Blotongan Kecamatan Sidorejo yang merupakan bekas terminal kota Salataiga. Lokasi ini memiliki kelas kesesuaian sesuai sehingga dapat teridentifikasi terkait kepadatan, kelerengan, penggunaan lahan dan aksesibilitas.
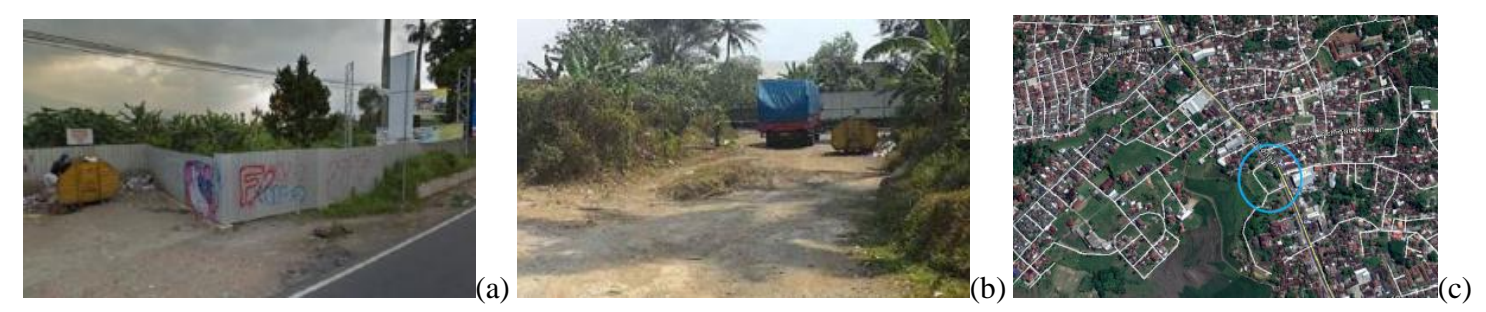

Sumber: Google Earth, 2017

Gambar 6. (a) \& (b) Kondisi Lokasi RTH Publik Aktif (c) Lokasi Prioritas RTH Publik Aktif

\section{KESIMPULAN}

Berdasarkan perhitungan kebutuhan RTH menurut luas wilayah dan jumlah penduduk memiliki kesenjangan sebesar $14,4 \%$ dan 0,68\% serta kesenjangan RTH Publik Aktif sebesar 0,68\%. Beberapa penyebab kurangnya RTH di Kota Salatiga yaitu belum optimalnya nilai KDH (Koefisien Dasar Hijau) sebagai penyumbang RTH privat, dan minimnya lahan yang dimiliki pemerintah untuk RTH Publik. Untuk itu perlunya dilakukan 
identifikasi terhadap lokasi yang potensial untuk dikembangkan menjadi RTH publik aktif, karena penentuan lokasi akan berpengaruh pada optimalnya RTH Publik Aktif pada suatu perkotaan. Penelitian ini menggunakanan analisis Weighted Overlay dengan mengambil nilai Percent of Influence atau bobot menggunakan metode Analytic Hierachy Proccess (AHP) terhadap narasumber ahli yang dipilih mewakili (1) Dinas Lingkungan Hidup, (2) Dinas Pekerjaan Umum dan Penataan Ruang, (3) Bappelitbangda Kota Salatiga dan (4) ahli Landscape Architecture. Responden dipilih karena 3 responden merupakan tim P2KH (Program Pengembangan Kota Hijau) Kota Salatiga dan memiliki pengetahuan lebih tentang RTH. Metode AHP menghasilkan nilai bobot terhadap empat variabel yaitu kepadatan, kelerengan, penggunaan lahan dan aksesibilitas yang digunakan untuk mengidentifikasi peta kesesuain lokasi RTH publik aktif. Peta tersebut memiliki masingmasing luas yaitu kelas sesuai sebesar $26,12 \%$,kelas cukup sesuai 59,27 \% dan kelas tidak sesuai $12,54 \%$ dari luas wilayah Kota Salatiga. Hasil kelas sesuai dan cukup sesuai menghasilkan 29 titik lahan milik pemerintah hasil analisis intersect menggunakan SIG yang sudah divalidasi terkait RTRW dan kondisi eksisiting. Terpilih lokasi yang menjadi prioritas utama berada di Kecamatan Sidorejo, sehingga ketentuan satu taman untuk satu kecamatan dapat terpenuhi sesuai degan Peraturan Menteri Pekerjaan Umum Nomor 05/PRT/M/2008. Penelitian ini menghasilkan peta kesesuiaan lokasi RTH Publik aktif berdasarkan variabel kriteria ruang publik Carr (1992) dan Achsan (2015).

\section{DAFTAR PUSTAKA}

Abbasi, A., Alalouch, C., \& Bramley, G. (2016). Open Space Quality in Deprived Urban Areas: User Perspective and Use Pattern. Procedia - Social and Behavioral Sciences (Vol. 216). Elsevier B.V. https://doi.org/10.1016/j.sbspro.2015.12.028

Achsan, A. C. (2015). Analisis Kesesuaian Lokasi Pengembangan Ruang Terbuka Hijau Publik Di Kecamatan Palu Timur Dan Palu Barat Suitability Analysis of The Location of The Development Public Green Open Space in The Sub District Palu Timur and Palu Barat, 1(2), 81-90.

Carr, S. (1992). Public Space. Cambridge: Press, Uni.

Chiara, J. De. (1997). Standar Perencanaan Tapak. Terjemahan Site Planning standards. Jakarta: Erlangga.

Direktorat Jendral Penataan Ruang. Department Pekerjaan Umum. Pedoman Penyediaan Dan Pemanfaatan Ruang Terbuka Hijau Di Kawasan Perkotaan, Pedoman Penyediaan Dan Pemanfaatan Ruang Terbuka Hijau Di Kawasan Perkotaan (2008).

Ekawati, S. D. (2016). Pembangunan Taman Kota Sebagai Ruang Terbuka Hijau Kawasan Perkotaan Purwokerto. Purwokerto: Universitas Jendral Sudirman.

Fan, P., Xu, L., Yue, W., \& Chen, J. (2017). Accessibility of public urban green space in an urban periphery: The case of Shanghai. Landscape and Urban Planning, 165, 177-192. https://doi.org/10.1016/j.landurbplan.2016.11.007

Ismaun, N. Y. \& I. (2011). RTH 30\% Resolusi Kota Hijau. Jakarta: PT Gramedia.

Miller, W., Collins, M. G., Steiner, F. R., \& Cook, E. (1998). An approach for greenway suitability analysis. Landscape and Urban Planning, 42(2-4), 91-105. https://doi.org/10.1016/S0169-2046(98)00080-2

Rojas, C., Páez, A., Barbosa, O., \& Carrasco, J. (2016). Accessibility to urban green spaces in Chilean cities using adaptive thresholds. JTRG, 57, 227-240. https://doi.org/10.1016/j.jtrangeo.2016.10.012

Rottle, N. D. (2015). Developing a Regional Open Space Strategy (ROSS) for Central Puget Sound, Washington State, USA. ELSEVIER, 62(2015), 133-138. https://doi.org/10.1016/j.envsci.2016.02.016

Rustama Hakim. (1987). Perancangan dalam Arsitektur Lansekap. Jakarta. 